\title{
Potential of Bacterial Isolates from a Stream in Manaus-Amazon to Bioremediate Chromium-Contaminated Environments
}

\author{
Ydrielly Veras Teles • Lorena Mota de Castro • Ézio Sargentini Junior • \\ Aryana Pinheiro do Nascimento $\cdot$ Henrique Alves da Silva $\cdot$ Rebeca Silveira Costa • \\ Rayane Delmontes do Nascimento Souza • Adolfo José da Mota • José Odair Pereira
}

Received: 9 October 2017 / Accepted: 1 July 2018 / Published online: 31 July 2018

(C) The Author(s) 2018

\begin{abstract}
Igarapé do Quarenta (IgQ), a stream located in the Manaus-AM, BR, has directly experienced the impacts of urban expansion over the last five decades, which contributed for its contamination. As an affluent of Rio Negro, IgQ also affects the water quality of this important river that bathes Manaus. However, the stress caused by the prolonged exposition to chemical agents may have selected microorganisms that exhibit great bioremediation potential. In the present study, bacteria isolated from four distinct sites of the IgQ were identified, and their potential to degrade hexavalent chromium $(\mathrm{Cr}(\mathrm{VI}))$ was investigated using the s-diphenylcarbazide method. Among the investigated isolates, 14 exhibited
\end{abstract}

Ydrielly Veras Teles and Lorena Mota de Castro contributed equally to this work.

Electronic supplementary material The online version of this article (https://doi.org/10.1007/s11270-018-3903-1) contains supplementary material, which is available to authorized users.

Y. V. Teles $(\bowtie) \cdot$ L. M. de Castro • A. P. do Nascimento • H. A. da Silva • A. J. da Mota · J. O. Pereira Universidade Federal do Amazonas, Av. General Rodrigo Octávio Jordão Ramos, 1200, Manaus, Amazonas, Brazil

e-mail: ydrielly@hotmail.com

\section{É. Sargentini Junior}

Instituto Nacional de Pesquisas da Amazônia, Av. André Araújo, 2396, Manaus, Amazonas, Brazil

\section{R. S. Costa • R. D. do Nascimento Souza}

Universidade do Estado do Amazonas, Av. Djalma Batista, 2470, Manaus, Amazonas, Brazil resistance against $\mathrm{Cr}(\mathrm{VI})$ at a concentration of $300 \mathrm{mg} / \mathrm{L}$ and eight isolates reduced over 50\% (53.5-97.4\%) chromium ratios after $72 \mathrm{~h}$ of incubation. Those isolates were identified by gene sequencing and classified in 10 genera (Acidovorax sp., Acinetobacter sp., Alicycliphilus sp., Bacillus sp., Comamonas sp., Enterobacter sp., Micrococcus sp., Proteus sp., Serratia sp., and Vagococcus sp.). Under control conditions, the isolate of Vagococcus sp. genus, in only $24 \mathrm{~h}$ of incubation, reduced $96.8 \%$ of the rate of $\mathrm{Cr}(\mathrm{VI})$ added to the culture medium at the concentration of $10 \mathrm{mg} / \mathrm{L}$. Obtained results indicate that the Vagococcus sp. exhibits a great potential to be used in the bioremediation of areas contaminated with chromium. The mechanisms of action of microorganisms should be investigated for more specific applications in the decontamination of effluents and direct use of its by-products to bioremediate polluted environments.

Keywords $\mathrm{Cr}(\mathrm{VI})$ degradation · Amazonian stream . Vagococcus $\mathrm{sp}$. Industrial area

\section{Introduction}

In the east side of Manaus, AM, BR, there is a watercourse known as Igarapé do Quarenta $(\operatorname{IgQ})$, which runs to the south side of the city where it meets the Igarapé do Educandos and flows into Rio Negro which is the largest affluent of the Amazon River. Since the establishment of Manaus Industrial District 
in the 1960s, the IgQ has being polluted with lots of domestic rejects and industrial effluents (Pinto et al. 2009; Torrezani et al. 2016).

This environmental problem requires special attention particularly in relation to the discharge of industrial effluents containing heavy metals, as it happens with chromium $(\mathrm{Cr})$. Chromium metal is found in nature in the form of trivalent chromium, $\mathrm{Cr}(\mathrm{III})$, and hexavalent chromium, $\mathrm{Cr}(\mathrm{VI})$. While $\mathrm{Cr}(\mathrm{III})$ is considered a more stable form of chromium, less toxic, and of low solubility, the $\mathrm{Cr}(\mathrm{VI})$ is highly soluble, carcinogenic, teratogenic, and mutagenic. $\mathrm{Cr}$ is able to penetrate the cells via phosphate and sulphate transporters (Puzon et al. 2002; Codd et al. 2003; Asmatullah et al. 1998). According to the International Agency for Research on Cancer (IARC 1990), the $\mathrm{Cr}(\mathrm{VI})$ is classified as carcinogenic to humans (group 1), though chromium metal and trivalent chromium compounds are not classifiable as human carcinogens (group 3).

In order to minimize the impacts caused by hazardous waste, the potential of microorganisms for the bioremediation of environments polluted with heavy metals has been extensively investigated. The Amazonian biodiversity certainly represents a significant source for the prospection of microorganisms effective in bioremediation processes (Pereira et al. 2017).

In general, endemic bacteria from environments contaminated with metals are adapted and able to metabolize such biohazard compounds, showing a variety of resistance strategies, tolerance, and decontamination capacity (Fuller et al. 2015; Thatoi et al. 2014). The combination of high tolerance and resistance with the ability to degrade $\mathrm{Cr}(\mathrm{VI})$ to $\mathrm{Cr}(\mathrm{III})$ is one of the most important parameters to be considered in studies for the screening of microorganisms with bioremediation potential (Dhal et al. 2010). The bacterial tolerance to chromium may involve various mechanisms of interaction between the microbiota and the metal, for example, binding of the metal to the cell wall, reduction of cell membrane permeability, active extrusion, absorption, and formation of complexes with chelating agents such as metallothioneins (De Filippis and Pallaghy 1994; Reed and Gadd 1990).

Our aims were the isolation and identification of $\mathrm{Cr}(\mathrm{VI})$-resistant bacteria collected from the IgQ waters and the evaluation of their potential to bioremediate chromium-contaminated environments.

\section{Material and Methods}

\subsection{Study Area and Sample Collection}

Bacterial isolates were collected from water samples at four sites along the IgQ course in Manaus-AM (Fig. 1): sample 1 - stream nascent at the Federal University of Amazonas, considered an unpolluted area $\left(3^{\circ} 06^{\prime} 00.44^{\prime \prime}\right.$ $\left.\mathrm{S}, 59^{\circ} 58^{\prime} 20.48^{\prime \prime} \mathrm{O}\right)$; sample 2-downstream ( $3^{\circ} 06^{\prime}$ $\left.25.57^{\prime \prime} \mathrm{S}, 59^{\circ} 57^{\prime} 38.32^{\prime \prime} \mathrm{O}\right)$ at the Industrial District region, where industrial effluents and domestic sewage are discharged located on New Republic neighborhood (acronym NR at the samples codes); sample 3-downstream ( $\left.3^{\circ} 07^{\prime} 01.02^{\prime \prime} \mathrm{S} 59^{\circ} 58^{\prime} 28.42^{\prime \prime} \mathrm{O}\right)$ area with increased discharge of domestic sewage and industrial effluents in the mediations of the State Department of Education and Quality of Teaching (SEDUC, acronym $\mathrm{SC}$ at the samples codes); and sample 4 - down by ( $3^{\circ}$ $07^{\prime} 56.14^{\prime \prime} \mathrm{S}, 60^{\circ} 00^{\prime} 02.50^{\prime \prime} \mathrm{O}$ ) area with huge discharge of domestic sewage nearby the debouch into the Igarapé do Educandos near a PROSAMIM (Social and Environmental Program of the Igarapés of Manaus, acronym $\mathrm{AC}$ at the samples codes) nucleus. Each site, with the aid of a Van Dorn bottle, was collected with $1 \mathrm{~L}$ of water. The water samples were collected according to the National Water Agency (ANA) recommendations (Brandão et al. 2011) and stored in refrigerated thermal boxes until their processing in laboratory.

\subsection{Bacterial Samples}

Saline solution $(0.9 \% \mathrm{NaCl})$ was used in the serial dilutions $1: 10$ at the ratios of $\left(10^{-1}, 10^{-2}, 10^{-3}, 10^{-4}\right.$, and $\left.10^{-5}\right)$. For each dilution, $100-\mu \mathrm{L}$ aliquot of the collected sample was plated, in triplicates, into Petri dishes containing tryptic soy agar (TSA), using the surface scattering technique, and the plates were incubated at $30^{\circ} \mathrm{C}$ in a bacteriological incubator for 5 days. The microorganisms were categorized based on their morphology and staining characteristics using the Gram staining method. A small amount of each pure colony was transferred to $1.5-\mathrm{mL}$ tubes containing TSA, medium supplemented with $20 \%$ glycerol, and cryopreserved at $-80{ }^{\circ} \mathrm{C}$.

\subsection{Susceptibility to Hexavalent Chromium Cr(VI)}

The collected colonies were standardized using the 0.5 McFarland turbidity standard and placed into 


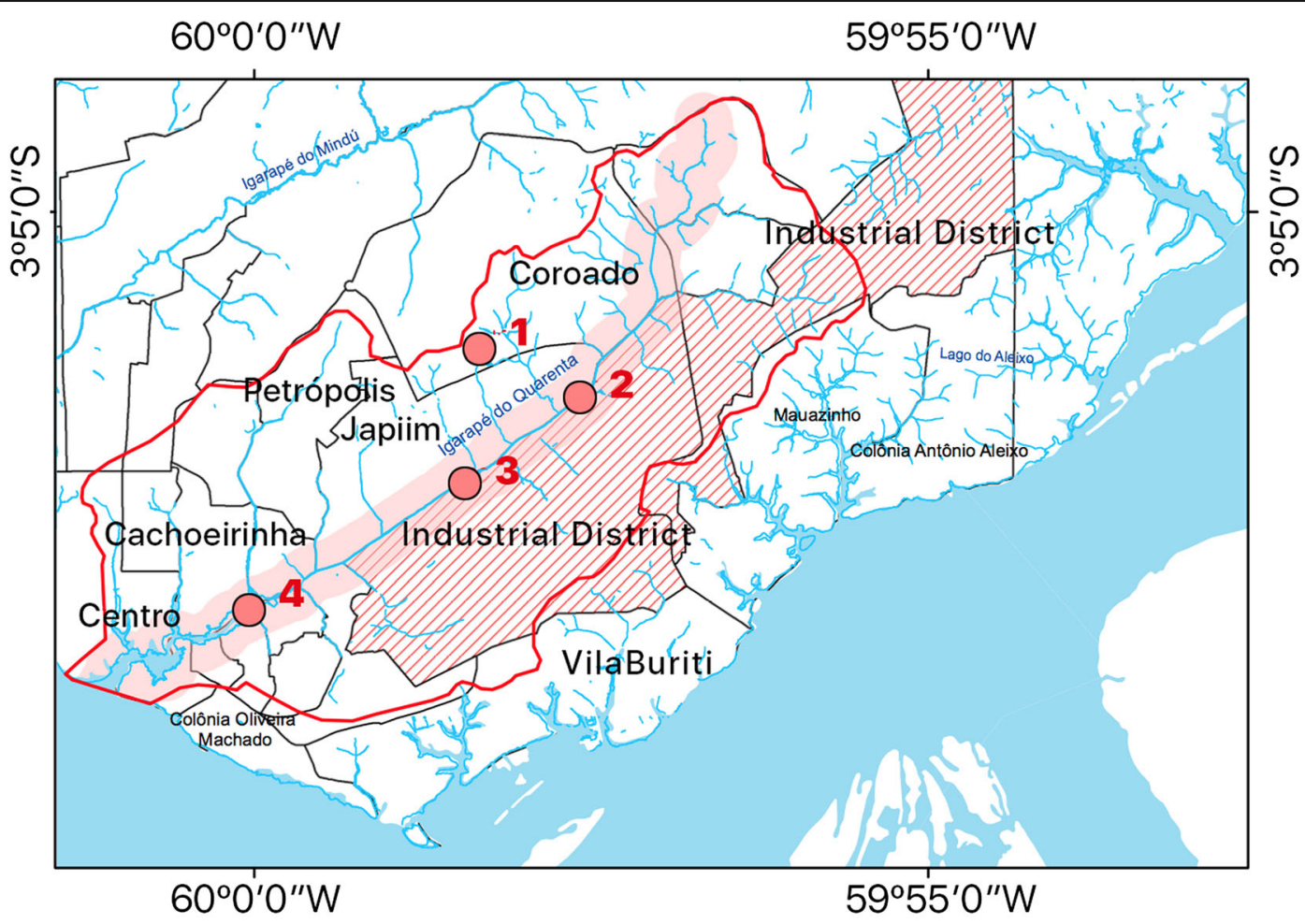

\section{Legend}

Sample points

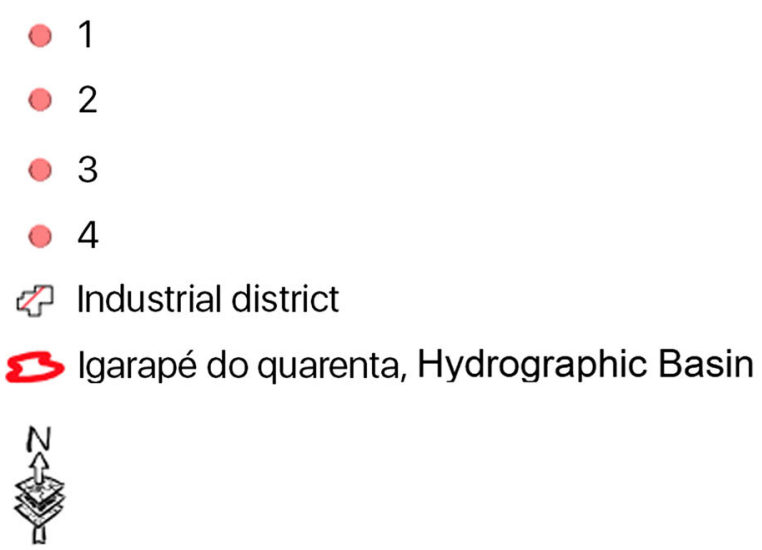

\section{Location of study area.}

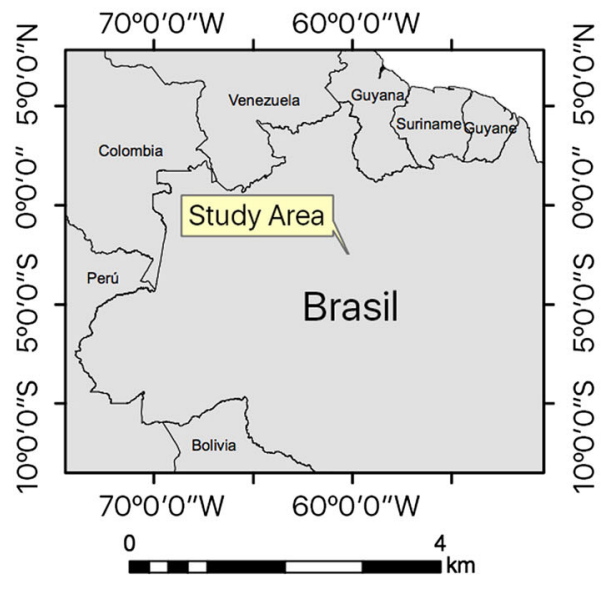

Fig. 1 Igarapé do Quarenta (IgQ) hydrographic basin: area of study and sample collection. Molecular phylogenetic analysis using maximum likelihood method

sterile 96-well microplates for microdilution procedures. Potassium dichromate $\left(\mathrm{K}_{2} \mathrm{Cr}_{2} \mathrm{O}_{7}\right)$ was used as the source of chromium(VI). The minimum inhibitory concentration (MIC) values were determined by observing the turbidity of the bacterial culture medium, which was plated on sterile 96well microplates containing $195 \mu \mathrm{L}$ of TSB broth supplemented with different concentrations of potassium dichromate $(0.1,1.0,10,15,100,200$, 300 , and $320 \mathrm{mg} / \mathrm{L}$ ) added with $5 \mu \mathrm{L}$ of each standardized isolate and incubated at $30{ }^{\circ} \mathrm{C}$ for 24 h (Giovanella et al. 2011; Netzahuatl-Muñoz et al. 2015; Upadhyay et al. 2017). Experiments were carried out in triplicate. 


\subsection{Molecular Identification and Phylogeny}

Genomic DNA of bacterial isolates resistant to $\mathrm{Cr}(\mathrm{VI})$ was extracted from fresh culture using the PureLink ${ }^{\circledR}$ Genomic DNA Mini Kit (Invitrogen by Thermo Fisher Scientific). The hypervariable regions from 16S rRNA gene were amplified by PCR with primers $400 \mathrm{~F}$ (5'GAG AGT TTG ATC CTG GCT CAG-3') and 1492 R (5'-CGG TGT GTA CAA GGC CCG GGA ACG-3') using the Platinum ${ }^{\circledR}$ Taq DNA Polymerase kit (Invitrogen by Thermo Fisher Scientific) under the following conditions: $10 \mathrm{ng}$ DNA template, $0.2 \mu \mathrm{M}$ of each primer, $0.2 \mathrm{mM}$ dNTPs, $1.5 \mathrm{mM} \mathrm{MgCl}_{2}, 1 \mathrm{X}$ PCR buffer, 1 IU Taq DNA polymerase enzyme, and ultrapure water to the final volume of $25 \mu \mathrm{L}$. The cycling conditions were an initial denaturation at $95{ }^{\circ} \mathrm{C}$ for $3 \mathrm{~min}$, followed by 30 cycles of $95{ }^{\circ} \mathrm{C}$ for $30 \mathrm{~s}, 59^{\circ} \mathrm{C}$ for $30 \mathrm{~s}, 72^{\circ} \mathrm{C}$ for $1 \mathrm{~min}$, and a single 7 -min step at $72{ }^{\circ} \mathrm{C}$. PCR products were purified using the PureLink $^{\mathrm{TM}}$ Quick PCR Purification kit (Invitrogen by Thermo Fisher Scientific) and sequenced with the BigDye Terminator v3.1 kit (Applied Biosystems ${ }^{\mathrm{TM}}$ by Thermo Fisher Scientific), following the manufacturer's recommendations. Sequences were analyzed using the automated genetic analyzer ABI 3500 (Applied Biosystems $^{\mathrm{TM}}$ by Thermo Fisher Scientific). The sequences were compared against the $16 \mathrm{~S}$ ribosomal RNA sequences (bacteria and archaea) from NCBINational Center for Biotechnology Information (http://ncbi.nlm.nih.gov) — using the BLASTn (Basic Local Alignment Search Tool).

The evolutionary history was inferred using the maximum likelihood method based on the Kimura 2parameter model (Kimura 1980). This model showed the lowest BIC score (Bayesian Information Criterion) in the best model tool. The analysis involved 25 nucleotide reference sequences, chosen from BLASTn result for each bacterial isolate searching. The phylogeny was determined using the bootstrap method with 1000 replicates (Felsenstein 1985). Initial tree(s) for the heuristic search were obtained automatically by applying Neighbor-Join and BioNJ algorithms to a matrix of pairwise distances estimated by the maximum composite likelihood (MCL) method and then selecting the topology with superior log likelihood value. A discrete gamma distribution was used to model evolutionary rate differences among sites $(5$ categories $(+\mathrm{G}$, parameter $=$ $0.5573)$ ). The rate variation model allowed for some sites to be evolutionarily invariable ([+I], 34.85\% sites).
All positions containing gaps and missing data were eliminated. Evolutionary analyses were conducted in MEGA7 (Kumar et al. 2016).

2.5 Evaluation of Bacterial Isolates Potential to Degrade $\mathrm{Cr}(\mathrm{VI})$

$\mathrm{Cr}(\mathrm{VI})$ quantification was performed using 3500-Cr D (diphenylcarbazide) - the standard colorimetric method for examination of water and wastewater (APHA 2012). All steps were followed to create the calibration curve (working range $0.01-1.0 \mathrm{mg} / \mathrm{L}$ ). Percentage reduction was evaluated individually for each bacterial isolate after determination of MIC values. At the end of $72 \mathrm{~h}$ of culture, $\mathrm{Cr}(\mathrm{VI})$-reduced concentration produced by each species was compared to control cultures (bacteria free).

\subsubsection{Simulation of $\mathrm{Cr}(\mathrm{VI})$-Contaminated Environment}

In order to determine which one of the evaluated bacterial isolate was more resistant to chromium, a water environment contaminated with 10 and $300 \mathrm{mg} / \mathrm{L}$ $\mathrm{Cr}(\mathrm{VI})$ was simulated.

Culture media were prepared with water collected in the IgQ nascent. The volume of water collected was filtered in $1.2-\mu \mathrm{m}$ pre-filter for removal of macroparticulates, and then in $0.45-\mu \mathrm{m}$ filter for removal of suspended particulate material, remaining only water-dissolved components as ions, metals, and organic compounds. Then, the filtrated water sample was autoclaved for $15 \mathrm{~min}$ at $121^{\circ} \mathrm{C}$.

The inoculum density was standardized in spectrophotometer by measuring absorbance at $600 \mathrm{~nm}$. A first experiment was performed to evaluate chromium degradation in medium similar to that $\mathrm{Cr}(\mathrm{VI})$-contaminated water environment, with or without addition of nutrients (Luria-Bertani medium-LB). The experiments were performed, in duplicate, using sterile beakers and cups oxygenated by compressors containing a $250-\mathrm{mL}$ sample. Nascent water added with $10 \mathrm{mg} / \mathrm{L} \mathrm{Cr}(\mathrm{VI})$ was used as control and for the experiments nascent water + $10 \mathrm{mg} / \mathrm{L} \mathrm{Cr}(\mathrm{VI})+\mathrm{LB}$ medium + bacterial isolate and nascent water $+10 \mathrm{mg} / \mathrm{L} \mathrm{Cr}(\mathrm{VI})+$ bacterial isolate.

A second experiment was carried out, in quadruplicate, to compare the growth of the selected isolates cultured in medium free of chromium and in medium added with $300 \mathrm{mg} / \mathrm{L} \mathrm{Cr}(\mathrm{VI})$. Samples were incubated in a rotary shaker (Shaker-CE-725) at $30{ }^{\circ} \mathrm{C}$ and $130 \mathrm{rpm}$. Growth curves based on the culture 
absorbance ratio were determined using a wavelength spectrophotometer at $600 \mathrm{~nm}$, in 24-h intervals.

Data of $\mathrm{Cr}(\mathrm{VI})$ concentrations from the two experiments, using the diphenylcarbazide method, as well as the $\mathrm{pH}$ measurement in experiments using $10 \mathrm{mg} / \mathrm{L}$ $\mathrm{Cr}(\mathrm{VI})$, were obtained every $12 \mathrm{~h}$ up to the final experimental period $(72 \mathrm{~h})$. The first measure occurred prior to the addition of the selected bacterial isolate. ShapiroWilk test was performed to evaluate normality of each replicate and the OriginPro 8 software was used for data analysis and graph plotting.

\section{Results and Discussion}

\subsection{Susceptibility of Microorganisms to $\mathrm{Cr}(\mathrm{VI})$}

Eighty-four microorganisms were isolated from the IgQ and all of them showed resistance to $\mathrm{Cr}(\mathrm{VI})$ at concentrations of $0.1,1.0,10,15$, and $100 \mathrm{mg} / \mathrm{L}$ of $\mathrm{K}_{2} \mathrm{Cr}_{2} \mathrm{O}_{7}$. From those 84 isolates, 35 exhibited resistance at concentrations up to $200 \mathrm{mg} / \mathrm{L}$ and only 23 isolates resisted to the concentration of $300 \mathrm{mg} / \mathrm{L}\left(\sim 106 \mathrm{mg} / \mathrm{L} \mathrm{Cr}^{6+}\right)$.

\subsection{Molecular Identification and Phylogeny of Isolates Resistant to $\mathrm{Cr}(\mathrm{VI})$}

Seventeen isolates, which exhibited greater chromium resistance, were grouped in 13 genera. Despite the limitation in identifying the isolates at the species level, the phylogenetic analysis showed consistent and distinct pattern for bacteria diversity (Fig. 2), most of them within the phylum Proteobacteria of the class Gammaproteobacteria. The details of the identification of the isolates resistant to $\mathrm{Cr}(\mathrm{VI})$ are described in Supplementary Table 1. Only one isolate for each cluster is shown on the phylogenetic tree, i.e., isolates with $100 \%$ 16S rRNA gene sequence identity, specifically SC10/ AC8 and NR10/NR13/NR16/NR19. All other isolates were not clustered using this criterion and therefore their sequences were clustered separately for the construction of phylogenetic trees. Using Gram staining technique, it was possible to determine that among isolates of 10 genera, 6 were Gram-negative bacillus, 2 Grampositive cocci, 1 Gram-positive bacillus, and only 1 Gram-negative coccobacillus.

Obtained results corroborate Bizani and Spagiari (2016) findings, who reported the resistance of Acetobacter aceti and Micrococcus luteus to hexavalent chromium at the concentration of $300 \mathrm{mg} / \mathrm{L}$ and metal reduction capacity of 36 and $38 \%$, respectively. Also, Upadhyay et al. (2017), investigating B. subtilis MNU16 tolerance to $\mathrm{Cr}(\mathrm{VI})$ and its reduction potential in concentrations of $50-300 \mathrm{mg} / \mathrm{L}$, observed that the isolate tolerance limit was $300 \mathrm{mg} / \mathrm{L} \mathrm{Cr}(\mathrm{VI})$. Moreover, Batool et al. (2014) evaluated the resistance of Pseudomonas aeruginosa and Ochrobactrum intermedium strains to hexavalent chromium at concentrations of 100, 500, and $1000 \mu \mathrm{g} / \mathrm{mL}$ and concluded that $\mathrm{Cr}(\mathrm{VI})$ stress significantly influence the morphology of bacteria altering characteristics of shape and size. The reported ability of some specific bacteria to tolerate high concentrations of $\mathrm{Cr}(\mathrm{VI})$ evidences their potential to bioremediate chromium-contaminated environments.

\subsection{Ability of IgQ Isolates to Reduce $\mathrm{Cr}(\mathrm{VI})$ at the Concentration of $300 \mathrm{mg} / \mathrm{L}$}

The efficiency of IgQ isolates in reducing $\mathrm{Cr}(\mathrm{VI})$ determined by s-diphenylcarbazide colorimetric method is shown in Fig. 3, which exhibits the profile of the isolates more resistant to hexavalent chromium after an exposure period of $72 \mathrm{~h}$. It was evidenced that the isolates of the genera Vagococcus sp. (NR06), Proteus sp. (NR16), Enterobacter sp. (AC8), and Bacillus sp. (NR10) collected at the IgQ sites 2 and 4 and cultured in TSB culture medium at $30{ }^{\circ} \mathrm{C}$, reduced $97.4,82.3,78.7 \%$, and $53.6 \%$ of $\mathrm{Cr}(\mathrm{VI})$ content, respectively, and were therefore considered the most effective.

Other genera such as Bacillus sp., Pseudomonas sp., Escherichia coli, and Proteus sp. were also investigated at similar concentrations and were efficient in bioremediation processes of wastewaters contaminated with Cr(VI) (Upadhyay et al. 2017; Drzewiecka 2016).

Serratia sp. and Proteus sp., both collected at IgQ site 2 , showed lower efficiency in reducing chromium levels, 18.6 and $24.8 \%$, respectively. It is probable that though their tolerance to heavy metals is high, they are not efficient to degrade chromium. Hacioglu and Tosunoglu (2014) also reported that the structure and function of microbial communities may be affected by heavy metals, resulting in mutations that influence adaptability or cause the microorganisms' death in heavy metal-impacted environments.

Isolates of the genera Acidovorax sp., Micrococcus sp., Acinetobacter sp., Alicycliphilus sp., and Comamonas sp., frequently found at IgQ site 3, exhibited $\mathrm{Cr}(\mathrm{VI})$-degrading ability in the range $34.5-54.7 \%$. 


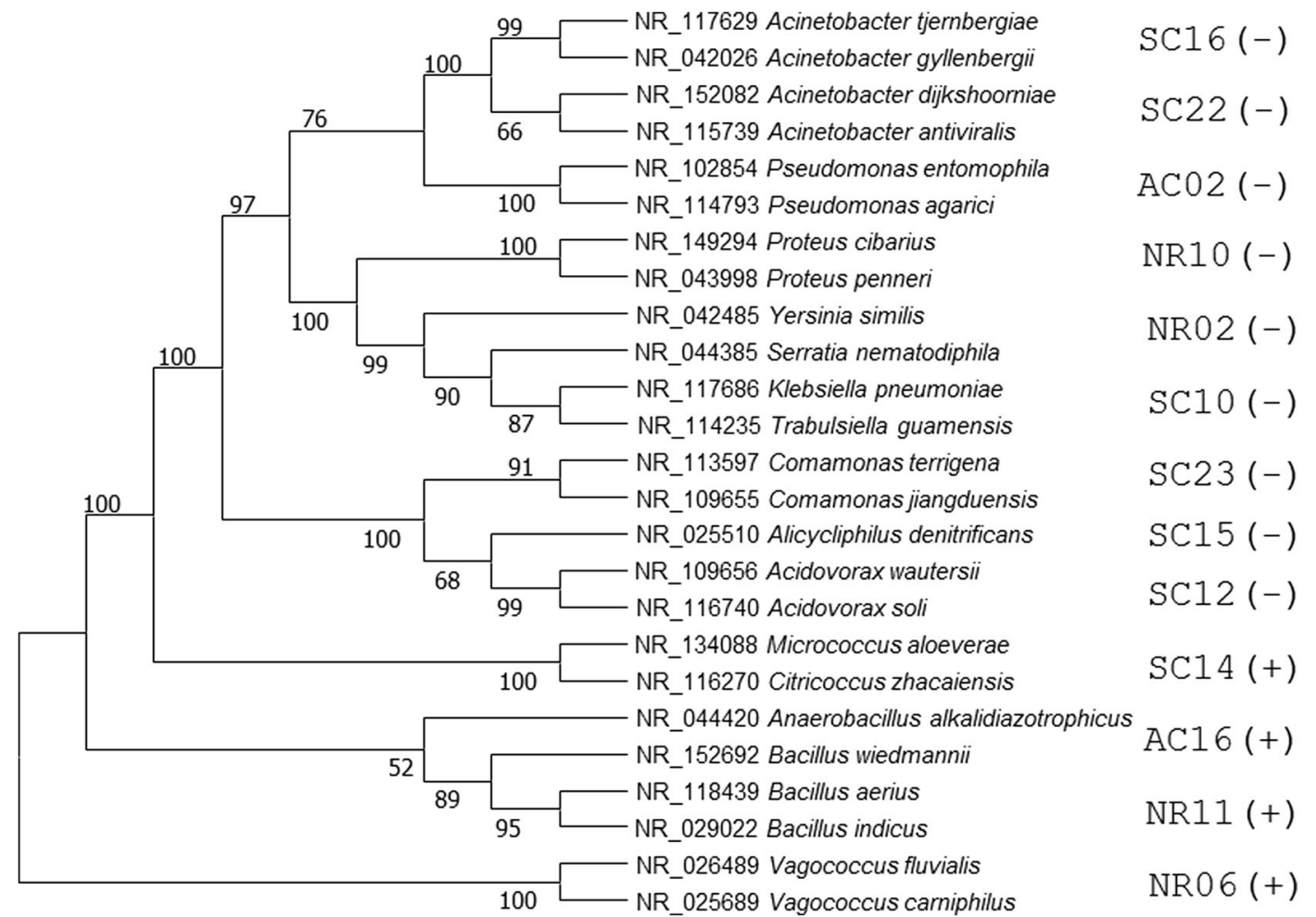

Fig. 2 Molecular phylogenetic analysis using maximum likelihood method. Gram stain result: (+) and (-)

Studies carried out by Dimitroula et al. (2015), Somenahally et al. (2013), Puyen et al. (2012), Srivastava and Thakur (2007), Liu et al. (2015), and Bestawy et al. (2013) investigated the role of microorganisms of those genera in Cr degradation processes. This work reports a first study on the potential of isolates of different genera collected in Amazon, which can be used in bioremediation processes.
Fig. 3 Rates of $\mathrm{Cr}(\mathrm{VI})$ after $72 \mathrm{~h}$ cultivation with IgQ isolates

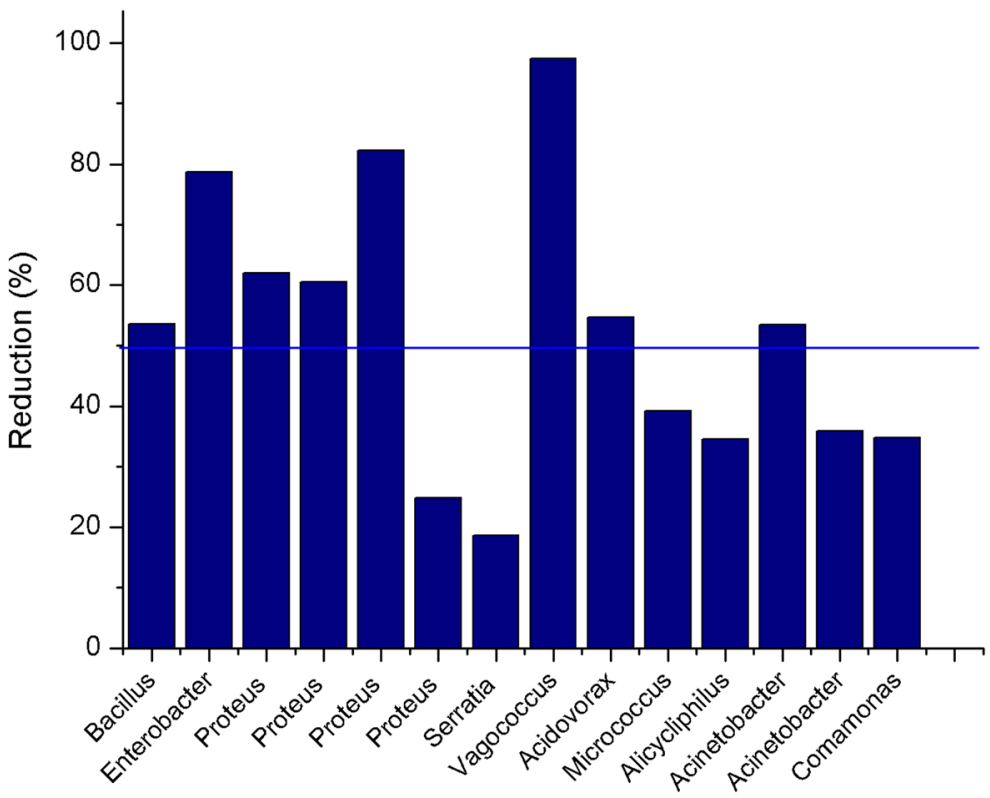




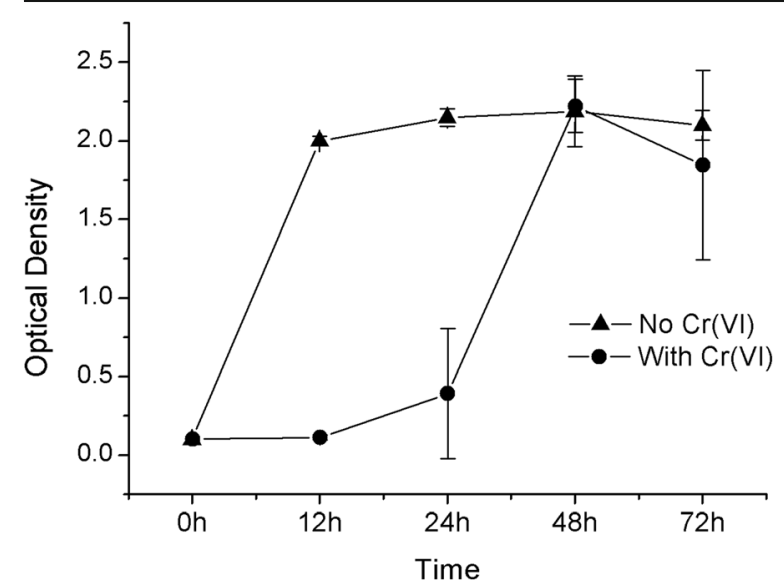

Fig. 4 Growth rates of Vagococcus sp. isolates in absence of chromium(VI) (- $\mathbf{\Delta}-)$ and in the presence of chromium(VI) (-•-) during $72 \mathrm{~h}$ with optical density measurement

\subsection{Growth Profile of Vagococcus sp.}

The genus Vagococcus is composed by Gram-positive bacteria formed by non-spore non-mobile cocci (Wang et al. 2011). According to Coleman (1988), Grampositive bacteria are more resistant to high concentrations of $\mathrm{Cr}(\mathrm{VI})$ if compared to Gram-negative bacteria. Vagococcus sp. cultured in medium devoid of chromium, in the first $12 \mathrm{~h}$, showed enhanced growth compared to that exhibited for isolates cultured in the presence of Cr(VI) (Fig. 4).

When exposed to $\mathrm{Cr}(\mathrm{VI})$, Vagococcus sp. isolates underwent an adaptation process during the first $24 \mathrm{~h}$. Only after that period of metabolic adjustment was evidenced their ability to degrade chromium. The maximum growth and adaptation of Vagococcus sp. to the chromium-supplemented medium were reached in $48 \mathrm{~h}$, evidencing its potential for bioremediation of effluents contaminated with $\mathrm{Cr}(\mathrm{VI})$. Shakoori and Muneer (2002) reported that Vagococcus sp. was able to degrade $\mathrm{Cr}(\mathrm{VI})$ to its nontoxic trivalent form. Those results reinforce the potential use of bacterial isolates on the decontamination of polluted environments and that bioremediation can be a strategic waste management tool harmless to animals, plants, and humans.

3.5 Assay Carried out with Vagococcus sp. in an IgQ-Simulated Environment

No Cr(VI) contamination was observed in IgQ waters when collecting the biological samples, but historical monitoring records of that bayou waters presented high levels of total chromium (between $158.4 \pm 164.6 \mathrm{mg} / \mathrm{L}$ ), according to Pio et al. (2013). The National Environmental Council legislation in force in Brazil (CONAMA 2011), for effluent releases, establishes that the maximum level of $\mathrm{Cr}(\mathrm{VI})$ permitted is $0.1 \mathrm{mg} / \mathrm{L}$. That legally recognized rate increased 100 times could simulate a contaminated environment. Therefore, to investigate the degrading potential of Vagococcus sp. isolates, two distinct conditions were established: IgQ water added with $10 \mathrm{mg} / \mathrm{L} \mathrm{Cr}(\mathrm{VI})$ and LB culture medium supplemented with IgQ and $10 \mathrm{mg} / \mathrm{L} \mathrm{Cr}(\mathrm{VI})$. Vagococcus sp. isolates cultured in LB medium practically reduced total chromium after $12 \mathrm{~h}$ of incubation while the isolates cultured in IgQ water degraded only small quantity of the metal (Fig. 5).
Fig. 5 Changes on $\mathrm{Cr}(\mathrm{VI})$ concentration during $72 \mathrm{~h}$ of culture of Vagococcus sp. isolates in medium simulating environmental conditions and in LB culture medium

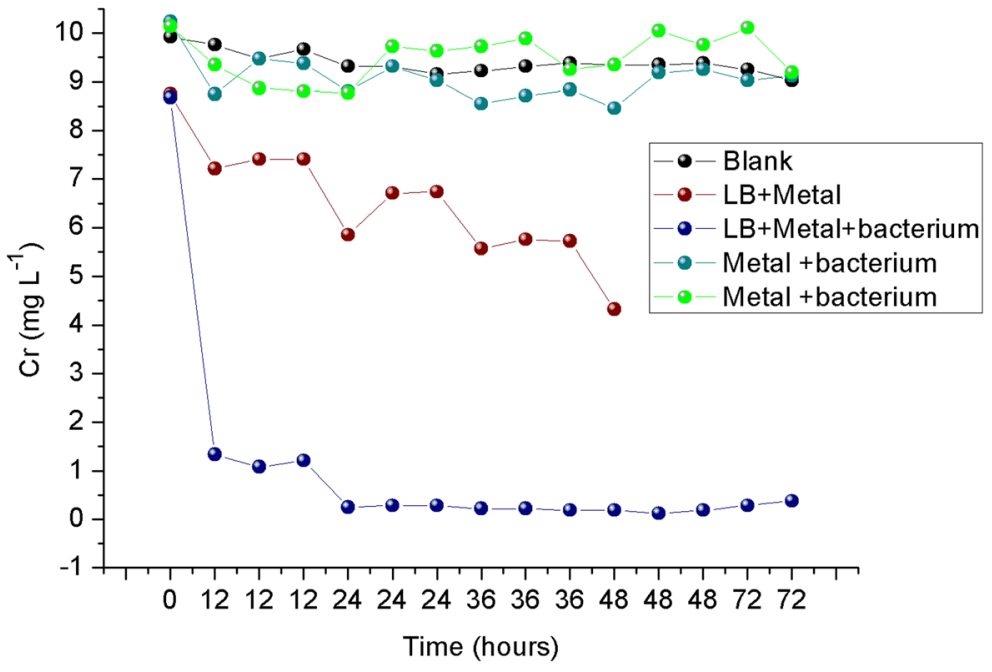


Fig. $6 \mathrm{pH}$ changes in the different simulated conditions

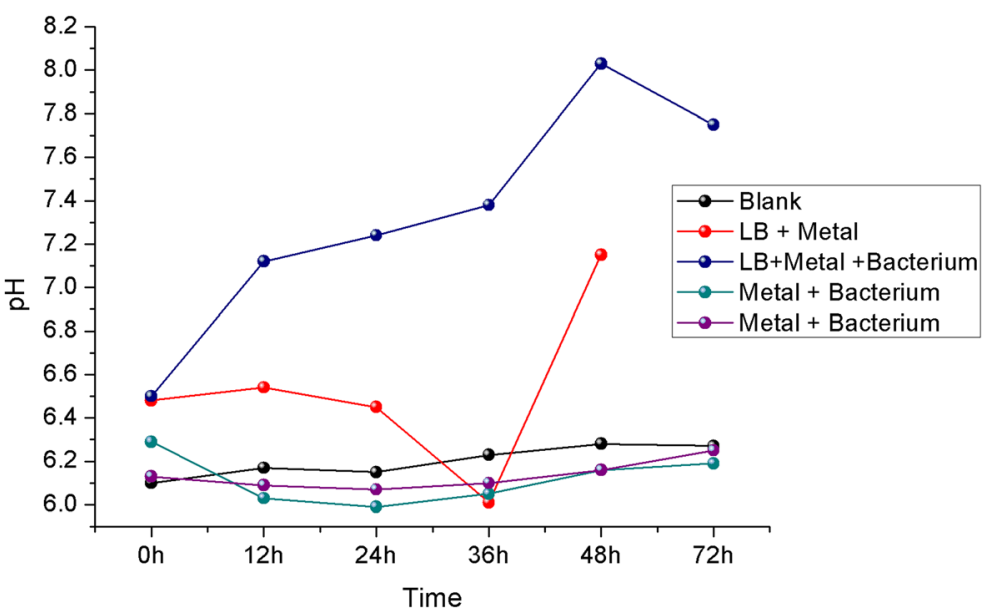

Experiments were carried out for $72 \mathrm{~h}$. Normality was determined by Shapiro-Wilk test $(p<0.05)$, replicates $(N=15)$, and a normal distribution with $W$ values (0.9248 and 0.9297) higher than critical value $(0.881)$, indicated the normality of the sample set. Variance analysis showed that in the absence of nutrients, the populations were not significantly different $(F$ statistics $=0.9029, p$ value $=0.851)$ and presented an average of $10.14 \%$ Cr reduction. Conversely, addition of nutrients in the medium promoted $96.18 \% \mathrm{Cr}(\mathrm{VI})$ degradation after 72 -h cultivation and $86.11 \%$ after the first $12 \mathrm{~h}$. To better adapt to chromium-impacted environments (simulated or real), bacteria requires a medium containing basic nutrients such as those found in unadulterated environments, so that their basic physiological needs can be maintained such as $\mathrm{pH}$, temperature, bioavailability of minerals, and nutrients (Olszewska et al. 2016).

Obtained results indicated that the nutrient medium devoid of bacterial inoculum also reduced $\mathrm{Cr}(\mathrm{VI})$. Experiments using only the LB basic medium after $24 \mathrm{~h}$ of culture presented a $\mathrm{Cr}(\mathrm{VI})$ reduction of $23 \%$. However, the highest chromium degradation potential was obtained in cultures added with Vagococcus (97.4\%). Pal and Paul (2004) reported that the addition of nutritional supplements to the medium increases degradation efficiency and they demonstrated that glucose $(1.0 \mathrm{~g} / \mathrm{L})$ added to the culture medium enhanced chromium degradation up to $55.5 \%$ after $24 \mathrm{~h}$ of incubation.

Regarding $\mathrm{pH}$ values, the Vagococcus sp. isolates cultured in LB medium added with chromium reacted differently compared to other strains (Fig. 6). The $\mathrm{pH}$ of the medium altered from 6.5 to 7.75 at the end of the experiment. Brandhuber et al. (2004) reported that this
$\mathrm{pH}$ change may be explained by the $\mathrm{Cr}(\mathrm{VI})$ reduction reaction that occurs as follows: $\mathrm{CrO}_{4}{ }^{2-}+8 \mathrm{H}^{+}+3 \mathrm{e}^{-} \rightarrow$ $\mathrm{Cr}^{3+}+4 \mathrm{H}_{2} \mathrm{O}$.

According to Conceição et al. (2007) and Somenahally et al. (2013), microorganisms have the ability to adapt to various environmental changes, as long as they are able to maintain the intracellular $\mathrm{pH}$ around 7.5 , a process that is achieved by the extrusion or intrusion of $\mathrm{H}^{+}$ions by the microbial cell. A trend curve following the equation $y=-0.08235 x+8.4706$ and $R^{2}=0.93658$ was established to validate $\mathrm{pH}$ values obtained in the experiment and it allowed to estimate that the concentration of $\mathrm{Cr}(\mathrm{VI})$ would reach zero after $102 \mathrm{~h}$. However, degradation of metal in culture of Vagococcus sp. isolates in medium containing chromium occurred within a maximum of $24 \mathrm{~h}$.

\section{Conclusion}

Obtained results indicated that Enterobacter sp., Bacillus sp., Proteus sp., Acidovorax sp., Acinetobacter sp., and Vagococcus sp. isolates collected in the IgQ are effective on the bioremediation of environments and effluents contaminated with $\mathrm{Cr}(\mathrm{VI})$. Moreover, Vagococcus sp. isolates showed significant ability to degrade $(\mathrm{Cr})$ or $\mathrm{Cr}(\mathrm{VI})$ at an initial concentration of $10 \mathrm{mg} / \mathrm{L}$ (96.8\% within $24 \mathrm{~h})$ and at higher concentration $(300 \mathrm{mg} / \mathrm{L})$; after $72 \mathrm{~h}$, those isolates drastically reduced $(97.4 \%)$ the metal. Those findings indicate that additional investigations on the pathways for chromium removal by Vagococcus sp. should be carried out. Furthermore, the efficiency of a consortium of isolates of different strains should be considered to investigate its 
ability to bioremediate Amazonian environments contaminated with heavy metals.

Acknowledgements The authors thank the Graduate Program in Biotechnology of the Federal University of Amazonas (UFAM) and the National Institute of Amazonian Research for all the collaboration.

Funding Information This study received financial support from the Amazonas Research Foundation (FAPEAM).

Open Access This article is distributed under the terms of the Creative Commons Attribution 4.0 International License (http:// creativecommons.org/licenses/by/4.0/), which permits unrestricted use, distribution, and reproduction in any medium, provided you give appropriate credit to the original author(s) and the source, provide a link to the Creative Commons license, and indicate if changes were made.

\section{References}

APHA - American Public Health Association; American Water Work Association - AWWA. (2012). Standard methods of the experimentation of water and wastewater. New York: WPCF.

Asmatullah, Qureshi, S. N., \& Shakoori, A. R. (1998). Hexavalent chromium-induced congenital abnormalities in chick embryos. Journal of Applied Toxicology. https://doi.org/10.1002 /(SICI)1099-1263(199805/06)18:3<167::AID-JAT492>3.0. $\mathrm{CO} ; 2-8$.

Batool, R., Yrjälä, K., \& Hasnain, S. (2014). Impact of environmental stress on biochemical parameters of bacteria reducing chromium. Brazilian Journal of Microbiology, 45(2), 573583.

Bestawy, E. E., Helmy, S., Hussien, H., Fahmy, M., \& Amer, R. (2013). Bioremediation of heavy metal-contaminated effluent using optimized activated sludge bacteria. Applied Water Science. https://doi.org/10.1007/s13201-012-0071-0.

Bizani, D., \& Spagiari, M. S. (2016). Behavioral kinetic evaluation and chromium reduction capacity by standard bacterial strains. Ciência e Natura. https://doi.org/10.5902/2179-460 X20196.

Brandão, C.J., et al. (2011). Guia nacional de coleta de amostras: água, sedimento, comunidades aquáticas e efluentes líquidas. São Paulo: CETESB; Brasília: ANA.

Brandhuber, P., Frey, M., McGuire, M. J., Chao, P., Seidel, C., Amy, G., Yoon, J., McNeill, L., \& Banerjee, K. (2004). Lowlevel hexavalent chromium treatment options: bench-scale evaluation. Denver: Awwa Research Foundation.

Codd, R., Irwin, J. A., \& Lay, P. A. (2003). Sialoglycoprotein and carbohydrate complexes in chromium toxicity. Current Opinion in Chemical Biology. https://doi.org/10.1016 /S1367-5931(03)00017-6.

Coleman, R. N. (1988). Chromium toxicity: effects on microorganisms with special reference to the soil matrix. In J. O.
Nriagu \& E. Nierboor (Eds.), Chromium in the natural and human environments (pp. 335-368). New York: Wiley.

CONAMA Resolution (2011). Dispõe sobre as condições e padrões de lançamento de efluentes, complementa e altera a Resolução $\mathrm{n}^{\circ} 357$, de 17 de março de 2005, do Conselho Nacional do Meio Ambiente National Environmental Council Resolution No. 430/2011 - DOU Publication: 13/ 05/2011. http://www.mma.gov.br/port/conama/legiabre. cfm? codlegi=646.

Conceição, D., Jacques, R., Bento, F., Simonetti, A., Selbach, P., \& Camargo, F. (2007). Redução de cromo hexavalente por bactérias isoladas de solos contaminados com cromo. Ciência Rural, 37(6), 1661-1667.

De Filippis, L. F., \& Pallaghy, C. K. (1994). Heavy metals: sources and biological effects. In L. C. Rai, J. P. Gaur, \& C. J. Soeder (Eds.), Advances in limnology series: algae and water pollution (pp. 31-77). Stuttgart: E. Scheizerbartsche Press.

Dimitroula, H., Syranidou, E., Manousaki, E., Nikolaides, N. P., Karatzas, G. P., \& Kalogerakis, N. (2015). Mitigation measures for chromium-VI contaminated groundwater - the role of endophytic bacteria in rhizofiltration. Journal of Hazardous Materials. https://doi.org/10.1016/j. jhazmat.2014.08.005.

Dhal, B., Thatoi, H. N., Das, N., \& Pandey, B. D. (2010). Reduction of hexavalent chromium by Bacillus sp. isolated from chromite mine soils and characterization of reduced product. Journal of Chemical Technology and Biotechnology. https://doi.org/10.1002/jctb.2451.

Drzewiecka, D. (2016). Significance and roles of Proteus spp. bacteria in natural environments. Microbial Ecology. https://doi.org/10.1007/s00248-015-0720-6.

Felsenstein, J. (1985). Confidence limits on phylogenies: an approach using the bootstrap. Evolution. https://doi.org/10.1111 /j.1558-5646.

Fuller, S. J., Burke, I. T., McMillian, D. G. G., Ding, W., \& Stewart, D. I. (2015). Population changes in a community of Alkaliphilic iron-reducing bacteria due to changes in the electron acceptor: implications for bioremediation at alkaline Cr(VI)-contaminated sites. Water, Air \& Soil Pollution. https://doi.org/10.1007/s11270-015-2437-z.

Giovanella, P., Bento, F., Cabral, L., Gianello, C., \& Camargo, F. A. O. (2011). Isolamento e seleção de micro-organismos resistentes e capazes de volatilizar mercúrio. Química Nova. https://doi.org/10.1590/S0100-40422011000200012.

Hacioglu, N., \& Tosunoglu, M. (2014). Determination of antimicrobial and heavy metal resistance profiles of some bacteria isolated from aquatic amphibian and reptile species. Environmental Monitoring and Assessment. https://doi. org/10.1007/s10661-013-3385-y.

IARC, International Agency for Research on Cancer. (1990). IARC monographs on the evaluation of carcinogenic risks to humans, chromium, nickel and welding. Lyon: International Agency for Research on Cancer.

Kimura, M. (1980). A simple method for estimating evolutionary rate of base substitutions through comparative studies of nucleotide sequences. Journal of Molecular Evolution. https://doi.org/10.1007/BF01731581.

Kumar, S., Stecher, G., \& Tamura, K. (2016). MEGA7: Molecular Evolutionary Genetics Analysis version 7.0 for bigger datasets. Molecular Biology and Evolution. https://doi. org/10.1093/molbev/msw054. 
Liu, L., Zhu, W., Cao, Z., Xu, B., Wang, G., \& Luo, M. (2015). High correlation between genotypes and phenotypes of environmental bacteria Comamonas testosteroni strains. BMC Genomics. https://doi.org/10.1186/s12864-015-1314-x.

Netzahuatl-Muñoz, A. R., Cristiani-Urbina, M. C., \& CristianiUrbina, E. (2015). Chromium biosorption from Cr(VI) aqueous solutions by Cupressus lusitanica bark: kinetics, equilibrium and thermodynamic studies. PLOS ONE, 10(9), e0137086. https://doi.org/10.1371/journal.pone.0137086.

Olszewska, M. A., Kocot, A. M., Nynca, A., \& ŁaniewskaTrokenheim, Ł. L. (2016). Utilization of physiological and taxonomic fluorescent probes to study Lactobacilli cells and response to $\mathrm{pH}$ challenge. Microbiological Research. https://doi.org/10.1016/j.micres.2016.07.011.

Pal, A., \& Paul, A. K. (2004). Aerobic chromate reduction by chromium-resistant bacteria isolated from serpentine soil. Microbiological Research. https://doi.org/10.1016/j. micres.2004.08.001.

Pereira, J. O., Souza, A. Q. L., Souza, A. D. L., \& França, S. C. (2017). Overview on biodiversity, chemistry, and biotechnological potential of microorganisms from the Brazilian Amazon. In Diversity and benefits of microorganisms from the tropics. In J. L. de Azevedo \& M. C. Quecine (Eds.), (pp. 71-103). Cham: Springer International Publishing. https://doi.org/10.1007/978-3-319-55804-2_5.

Pinto, A. G. N., et al. (2009). The human action effects on the hydrogeochemistry of Negro river at the Manaus shoreline. Acta Amazonica, 39(3), 627-638.

Pio, M. C. S., Souza, K. S., \& Santana, G. P. (2013). Capacidade da Lemna aequinoctialis para acumular metais pesados de água contaminada. Acta Amazonica, 43(2), 203-210.

Puyen, Z. M., Villagrasa, E., Maldonado, J., Diestra, E., Esteve, I., \& Solé, A. (2012). Biosorption of lead and copper by heavymetal tolerant Micrococcus luteus DE2008. Bioresource Technology. https://doi.org/10.1016/j.biortech.2012.09.036.

Puzon, G. J., Petersen, J. N., Roberts, A. G., Kramer, D. M., \& Xun, L. (2002). A bacterial flavin reductase system reduces chromate to a soluble chromium(III)-NAD+ complex. Biochemical and Biophysical Research Communications. https://doi.org/10.1016/S0006-291X(02 )00438-2.

Reed, R. H., \& Gadd, G. M. (1990). Metal tolerance in eukaryotic and prokaryotic algae. In A. J. Shaw (Ed.), Heavy metal tolerance in plants: evolutionary aspects (pp. 105-118). Boca Raton: CRC Press.

Shakoori, A. R., \& Muneer, B. (2002). Copper-resistant bacteria from industrial effluents and their role in remediation of heavy metals in wastewater. Folia Microbiologica. https://doi.org/10.1007/BF02818564.

Somenahally, A. C., Mosher, J. J., Yuan, T., Podar, M., Phelps, T. J., et al. (2013). Hexavalent chromium reduction under fermentative conditions with lactate stimulated native microbial communities. PLoS One. https://doi.org/10.1371/journal. pone. 0083909 .

Srivastava, S., \& Thakur, I. S. (2007). Evaluation of biosorption potency of Acinetobacter sp. for removal of hexavalent chromium from tannery effluent. Biodegradation. https://doi. org/10.1007/s10532-006-9096-0.

Thatoi, H., Das, S., Mishra, J., \& Rath, B. P. (2014). Bacterial chromate reductase, a potential enzyme for bioremediation of hexavalent chromium: a review. Journal of Environmental Management. https://doi.org/10.1016/j.jenvman.2014.07.014.

Torrezani, L., Sargentini Junior, É., \& Santana, G. P. (2016). Índice de geoacumulação de mercúrio na bacia do Igarapé do Educandos (Manaus/Amazonas). Journal of Chemical Engineering and Chemistry. https://doi.org/10.18540 /2446941602032016161.

Upadhyay, N., Vishwakarma, K., Singh, J., et al. (2017). Tolerance and reduction of chromium(VI) by Bacillus sp. MNU16 isolated from contaminated coal mining soil. Frontiers in Plant Science. https://doi.org/10.3389/fpls.2017.00778.

Wang, L., Cui, Y. S., Kwon, C. S., Lee, S. T., Lee, J. S., \& Im, W. T. (2011). Vagococcus acidifermentans sp. nov., isolated from an acidogenic fermentation bioreactor. International Journal of Systematic and Evolutionary Microbiology. https://doi.org/10.1099/ijs.0.022087-0. 